\title{
A Method for Producing Bioethanol from the Lignocellulose of Shorea uliginosa Foxw. by Enzymatic Saccharification and Fermentation
}

\author{
Wahyu Dwianto ${ }^{1}$, Fitria ${ }^{1}$, Ika Wahyuni ${ }^{1}$, Danang Sudarwoko Adi ${ }^{1}$, Sri Hartati ${ }^{2}$, \\ Rumi Kaida $^{3}$ \& Takahisa Hayashi ${ }^{3}$ \\ ${ }^{1}$ Research Center for Biomaterials, Indonesian Institute of Sciences, \\ Jalan Raya Bogor km 46, Cibinong, Bogor, Indonesia 16911 \\ ${ }^{2}$ Research Center for Biotechnology, Indonesian Institute of Sciences \\ Jalan Raya Bogor km 46, Cibinong, Bogor, Indonesia 16911 \\ ${ }^{3}$ Department of Bioscience, Tokyo University of Agriculture \\ 1-1-1 Sakuragaoka, Setagaya-ku, Tokyo 156-8502, Japan \\ Email:wahyudwianto@yahoo.com
}

\begin{abstract}
Several papers have reported various technical aspects of lignocellulosic bioethanol production. Recalcitrance to saccharification is a major limitation for conversion of lignocellulosic biomass to ethanol. The biological process for converting lignocellulose to fuel ethanol includes delignification in order to liberate cellulose and hemicelluloses, depolymerization of carbohydrate polymers to produce free sugars, and sugar fermentation to produce ethanol. Access of plant cell wall polysaccharides to chemical, enzymatic and microbial digestion is limited by many factors, including the presence of lignin and hemicellulose that cover cellulose microfibrils. An effort to support the fuel ethanol fermentation industry using the Indonesian woody plant species Shorea uliginosa Foxw. was undertaken with regard to the established efficient bioethanol production process. This paper relates to a method for producing bioethanol from the lignocellulose of $S$. uliginosa Foxw. by saccharification and fermentation of xylem. A literature study of previous research on cellulose hydrolysis as a method for producing bioethanol was necessary. The objective of this study was to gain a deeper understanding of the degradation mechanisms of cellulose by enzymes through a study of previous research, which were then compared to the new method.
\end{abstract}

Keywords: enzymatic hydrolysis; ethanol; lignocelluloses; S. uliginosa Foxw.; xylem.

\section{$1 \quad$ Introduction}

Cost-effectively making ethanol from cellulose is a national priority as well as a scientific challenge. With crude oil prices stubbornly stuck around $\$ 100 /$ barrel, the world is now facing an energy crisis at a level that has never been seen before. Considering this fact, the U.S. Congress has passed the Energy Independence and Security Act of 2007 that mandates the production of 36 billion gallons of bioethanol, where 20 billion of those are from starch

Received October $29^{\text {th }}, 2013$, Revised November $22^{\text {nd }}, 2013$, Accepted for publication June $11^{\text {th }}, 2014$

Copyright (C) 2014 Published by ITB Journal Publisher, ISSN: 2337-5760, DOI: 10.5614/j.math.fund.sci.2014.46.2.5 
(currently 9 billion) and 16 billion from cellulose (currently none) by 2022 . Utilization of starch (mostly corn) as a source of ethanol has recently come into question because it competes with food supply, which led many to call starchbased ethanol a "devil's trade, food versus fuel". Hence, the focus is increasingly turning to cellulose (over one half of all global biomass) as the ultimate source for bioethanol [1].

Selective and effective separation of the main fractions present in lignocellulose biomass is of great interest, mainly when subsequently a submerged fermentation process will be performed, because the by-products obtained during hydrolysis of these materials may affect the fermentation yield and also because valuable sources are lost if other fractions are partially hydrolyzed. Since the structure of the plant cell wall components - cellulose, hemicelluloses and lignin - and the way they are linked with each other make it difficult to separate them, finding a suitable and effective separation process is quite a challenge. It can be in the form of biological, chemical, or physical processes, or a combination thereof. A number of effective mechanisms to perform the separation in view of facilitating the hydrolysis process of cellulose are given below.

The most frequent procedures to hydrolyze cellulose are chemical and enzymatic processes [2]. The chemical method, also known as concentrated acid hydrolysis, is conducted with mineral acids such as $\mathrm{H}_{2} \mathrm{SO}_{4}$ or $\mathrm{HCl}$ (in the range of $10 \sim 30 \%$ ), at a temperature of about $160^{\circ} \mathrm{C}$ and a pressure of about $10 \mathrm{~atm}[3$, 4]. The crystalline part of the cellulose makes this typical severe operation necessary in order to enable the cellulose to detach itself from its complex structure. However, this must be done warily so that by-products from the degradation of the important cellulose can be prevented. Hemicelluloses also need to be degraded with the presence of strong acids [2].

Moreover, corrosion issues can be avoided in the application of this method, while the advantage of minimum by-products and maximum whole glucose can be obtained, which is necessary for successful fermentation [2]. Enzymatic hydrolysis of cellulose is a reaction carried out by several cellulose-degrading enzymes: (1) endo-1,4- $\beta$-glucanase (EC 3.2.1.4), which attacks the amorphous regions of cellulose microfibrils; (2) exo-1,4- $\beta$-glucanases (EC 3.2.1.91, CBH as cellobiohydrolase), which attack their crystalline regions by removing cellobiose units either from the non-reducing ends or the reducing ends; (3) $\beta$ glucosidase (EC 3.2.1.21), which hydrolyzes cellobiose to produce glucose [36]. Many microbes, either bacteria or fungi, have been explored in order to find the most suitable one to be applied in enzymatic hydrolysis. One of these is Trichoderma reesei. However, T. reesei cellulases and their improvement 
achieved by conventional techniques do not have adequate efficiency to make enzymatic cellulosic ethanol production economically viable at this time.

Due to the structural composition of lignocellulosic biomass, it has to go through a pretreatment process to make the cellulose easily penetrated during the enzymatic hydrolysis [2,7-9]. In this study, we applied simultaneous sacharification and fermentation (SSF) processes that have greater advantages compared to separate enzymatic hydrolysis and fermentation (SHF), since the inhibition effects of cellobiose and glucose to the enzyme are minimized by keeping a low concentration of these sugars in the media [10].

\section{$2 \quad$ Materials and Methods}

\subsection{Ethanol Production}

A piece of stem wood of $S$. uliginosa Foxw. was cut from a mature tree at a height of 2 to $3 \mathrm{~m}$ above the ground. The bark was peeled and the wood was airdried. The wood was then milled into a powder.

A mixture containing the powder of wood preparation $(100 \mathrm{mg})$ in $2 \mathrm{ml}$ of 50 $\mathrm{mM}$ sodium acetate buffer, $\mathrm{pH} 4.8,0.02 \%$ Tween, 0.4 filter paper units of a cellulase preparation $(2.0 \mathrm{mg})$ and a seed culture of Saccharomyces cervisiae (SH1089) with yeast nutrients $\left(4 \mathrm{mg}\left(\mathrm{NH}_{4}\right)_{2} \mathrm{HPO}_{4}, 0.2 \mathrm{mg} \mathrm{MgSO}{ }_{4} .7 \mathrm{H}_{2} \mathrm{O}\right.$, and 8 mg yeast extract) was prepared. The mixture was incubated at $45^{\circ} \mathrm{C}$ in a rotary shaker set at $135 \mathrm{rpm}$. Each mixture was then subjected to simultaneous enzymatic saccharification and fermentation. About $100 \mu \mathrm{L}$ of the supernatant was collected at $6 \mathrm{~h}, 12 \mathrm{~h}, 24 \mathrm{~h}$, and $48 \mathrm{~h}$ of hydrolysis and then used for ethanol analysis. The ethanol formed was measured by gas chromatography on a Supelcowax-10 column ( $0.53 \mathrm{~mm}$ i.d. x $15 \mathrm{~m}$; Supelco, Bellefonte, PA, USA) at $50^{\circ} \mathrm{C}$ using an Agilent gas chromatograph. Isopropanol was used as an internal standard.

\subsection{Chemical Analysis}

The wood powder was extracted 4 times successively with water and $24 \% \mathrm{KOH}$ containing $0.1 \% \mathrm{NaBH}_{4}$. The alkali-soluble fraction was neutralized, dialyzed, and freeze-dried for use in methylation analysis. Partially methylated alditol acetates were analyzed using an Agilent gas chromatography-mass spectrometer (Santa Clara, CA, USA) with a glass capillary column $(0.25 \times 15 \mathrm{~m})$ of DB-225. Each alditol-acetate was identified by its retention time and mass spectrum. The amount of cellulose was determined by measuring the acid-insoluble residue; the samples were extracted with acetic/nitric reagent $(80 \%$ acetic acid/concentrated nitric acid, 10:1) in a boiling water bath for $30 \mathrm{~min}$. The 
resulting insoluble material was washed in water, air-dried and the amount of cellulose was measured. Lignin content was determined by the Klason method.

\section{$3 \quad$ Results and Discussion}

When saccharification was accompanied by fermentation with yeast, ethanol production was $22.0 \mathrm{mg} / 100 \mathrm{mg}$ xylem in the enzymatic hydrolysate of the wood of S. uliginosa Foxw. The trend of ethanol production was similar to the trend of saccharification of the wood with cellulase preparation. The level of cellulose hydrolysis was almost complete at $48 \mathrm{~h}$ (Table 1). Based on chemical analyses, the level of cellulose in the wood of S. uliginosa Foxw. was 50.5\% while its lignin content was $22.1 \%$. The content of lignin in the wood was smaller than that of sengon (Paraserianthes falcataria), being 26.5\% [11]. Based on methylation analysis of the hemicellulose fraction, the wood contained $0.1 \%$ of 4,6 -linked glucose and $14.7 \%$ of 4-linked xylose, showing that the content of hemicelluloses $(19.6 \%)$ was smaller than that of sengon $(21.0 \%)[11]$.

Table 1 Saccharification and chemical components of S. uliginosa Foxw.

\begin{tabular}{lc}
\hline \multicolumn{1}{c}{ Components } & Persentage (\%) \\
\hline Saccharification 48 h & 52.6 \\
Cellulose & 50.5 \\
Lignin & 22.1 \\
Hemicellulose & 19.6 \\
4-linked Xylose & 14.7 \\
4,6-linked Glucose & 0.1 \\
Ash & 2.7 \\
\hline
\end{tabular}

Our invention gives almost complete hydrolysis of lignocellulose of the wood of $S$. uliginosa Foxw., even though lignocellulose is believed to be recalcitrant to enzymatic saccharification. In addition, this invention provides a systematic method for using the wood of the S. uliginosa Foxw. tree as a lignocellulosic material for bioethanol production by saccharification and fermentation of xylem.

Low levels of xyloglucan and glucomannan along with a low lignin deposition in wood have been linked to the method for producing bioethanol from lignocellulose with an enzyme preparation. The surface of cellulose microfibrils may be less intercalated with xyloglucan. Therefore, our invention also shows that xyloglucan serves as a key hemicellulose and a tightening tether for the cellulose microfibrils in the secondary walls. The hydrolysis of the cellulose microfibrils by a cellulase preparation will have a higher rate if the amount of tether decreases in the wood. The level of recalcitrant compounds with regard to 
saccharification with cellulase enzyme preparation is lower compared to that of other trees. Therefore, there is no need for pretreatment of the wood before saccharification with fermentation.

Cellulase does not easily hydrolyze 1,4- $\beta$-glucans (cellulose microfibrils) intercalated with xyloglucan, nor does xyloglucanase efficiently attack xyloglucan in wood when the wood is subjected to saccharification with any commercial cellulase preparation. Xyloglucans intercalate tightly into cellulose microfibrils in wood because further elongation and expansion of the plant cells (fiber cells in wood) tighten and fix the intercalation between 1,4- $\beta$-glucan and xyloglucan during growth. Lignin is also bound to glucomannan, whose degradation could also reduce lignin deposition in the walls, because lignin is known to be a recalcitrant compound in cellulose hydrolysis.

Cellulose produced by plants is composed of both highly amorphous regions containing large voids and other irregularities, as well as a tightly packed crystalline region [12]. This region is frequently accepted as the reason behind the reactivity of a substrate [13]. The rate of cellulose hydrolysis mediated by fungal cellulases is typically 3-30 times faster for amorphous cellulose as compared to high crystalline cellulose [13]. Comparing the hydrolysis rates and the high level of crystalinty of S. uliginosa Foxw., it can be assumed that accessibility of cellulose is a more important factor in determining the hydrolysis rate than the crystallinity index.

\section{Conclusions}

The present invention relates to a method for producing bioethanol from lignocellulose of $S$. uliginosa Foxw. by saccharification and fermentation of its xylem. S. uliginosa Foxw. has a lower level of recalcitrant compounds with regard to saccharification with a cellulase enzyme preparation compared to other trees. Therefore, there is no need for pretreatment of the wood before saccharification with fermentation.

\section{References}

[1] Chakrabarti, R., Wu, R. \& Rabitz, H., Quantum Multiobservable Control, Physical Review, A 77(06325), pp. 1-11, 2008.

[2] Mussatto, S.I. \& Teixeira, J.A., Lignocellulose as Raw Material in Fermentation Processes, Current Research, Technology and Education Topics in Applied Microbiology and Microbial Biotechnology, A. Mendez-Vilas, ed., pp. 897-907, 2010.

[3] Sun, Y. \& Cheng, J., Hydrolysis of Lignocellulosic Materials for Ethanol Production: A Review, Bioresource Technology, 83, pp. 1-11, 2002. 
[4] Kumar, P., Barrett, D.M., Delwiche, M.J. \& Stroeve, P., Methods for Pretreatment of Lignocellulosic Biomass for Efficient Hydrolysis and Biofuel Production, Industrial \& Engineering Chemistry Research, 48, pp. 3713-3729, 2009.

[5] Cao, Y. \& Tan, H., Effects of Cellulase on the Modification of Cellulose, Carbohydrate Research, 337, pp. 1291-1296, 2002.

[6] Prasad, S., Singh, A. \& Joshi, H.C., Ethanol as An Alternative Fuel from Agricultural, Industrial and Urban Residues, Resources, Conservation and Recycling, 50, pp. 1-39, 2007.

[7] Martin, C., Galbe, M., Nilvebrant, N.O. \& Jonsson, L.J., Comparison of the Fermentability of Enzymatic Hydrolyzates of Sugarcane Bagasse Pretreated by Steam Explosion Using Different Impregnating Agents, Applied Biochemistry and Biotechnology, 98-100, pp. 699-716, 2002.

[8] Varga, E., Szengyel, Z. \& Reczey, K., Chemical Pretreatments of Corn Stover for Enhancing Enzymatic Digestibility, Applied Biochemistry and Biotechnology, 98-100, pp. 73-87, 2002.

[9] Berlin, A., Gilkes, N., Kilburn, D., Bura, R., Markov, A., Skomarovsky, A., Okunev, O., Gusakov, A., Maximenko, V., Gregg, D., Sinitsyn, A. \& Saddler, J., Evaluation of Novel Fungal Cellulase Preparations for Ability to Hydrolyze Softwood Substrates-Evidence for the Role of Accessory Enzymes, Enzyme and Microbial Technology, 37, pp. 175-184, 2005.

[10] Taherzadeh, M. \& Karimi, K., Enzyme-based Hydrolysis Processes for Ethanol from Lignocellulosic Materials: A Review, Bioresources, 2(4), pp. 707-738, 2007.

[11] Kaida. R., Kaku, T., Baba, K., Hartati, S., Sudarmonowati, E. \& Hayashi, T., Enhancement of Saccharification by Overexpression of Poplar Cellulase in Sengon, J. Wood Sci., 55, pp. 435-480, 2009.

[12] Carere, C., Sparling, R., Cicek, N. \& Levin, D., Third Generation Biofuels via Direct Cellulose Fermentation, International Journal of Molecular Science, 9, pp. 1342-1360, 2008.

[13] Zhang, Y. \& Lynd, L. Toward An Aggregated Understanding of Enzymatic Hydrolysis of Cellulose: Noncomplexed Cellulase Systems, Biotechnology and Bioengineering, 88(7), pp. 797-824, 2004. 